\title{
Comparison of fetal bovine serum and platelet-rich plasma on human lipoaspirate-derived mesenchymal stem cell proliferation
}

\author{
Des Suryani, ${ }^{1}$ Jeanne A. Pawitan, ${ }^{2}$ Jinia Lilianty, ${ }^{3}$ Reza Y. Purwoko, ${ }^{3,4}$ Isabella K. Liem, ${ }^{5}$ Lia Damayanti ${ }^{2}$ \\ ${ }^{1}$ Biomedical Science Master Program, Faculty of Medicine, Universitas Indonesia, Jakarta, Indonesia \\ ${ }^{2}$ Departement of Histology, Faculty of Medicine, Universitas Indonesia, Jakarta, Indonesia \\ ${ }^{3}$ Erpour skin care, Jakarta, Indonesia \\ ${ }^{4}$ Biomedical Science Doctoral Program,Faculty of Medicine, Universitas Indonesia, Jakarta, Indonesia \\ ${ }^{5}$ Department of Anatomy, Faculty of Medicine, Universitas Indonesia, Jakarta, Indonesia
}

\begin{abstract}
Abstrak
Latar belakang: Sel punca asal lipoaspirat (SPL) sangat menjanjikan di bidang kedokteran regeneratif, misalnya untuk menyembuhkan infark miokard akut. Untuk memperbanyak sel punca biasanya digunakan medium yang mengandung fetal bovine serum (FBS). Akan tetapi, untuk aplikasi klinis, FBS mengandung xeno-protein yang mungkin menimbulkan reaksi imun dan penolakan bila diberikan pada pasien. Platelet rich plasma (PRP) adalah salah satu calon pengganti FBS. Penelitian ini bertujuan membandingkan proliferasi SPL yang dikultur dalam medium yang mengandung 5\% PRP, 10\%

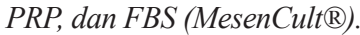

Metode: SPL dikultur dalam DMEM 5\% PRP, DMEM/10\% PRP dan MesenCult $\circledast$. Sesudah kultur primer menjadi konfluens, sel dipanen menggunakan TrypLE Select, dan ditabur kembali (sekitar 20.000 sel hidup) pada wadah baru, dalam medium yang sama dengan sebelumnya. Pasase dilakukan sampai pasase-5, dengan enam replikasi. Population doubling time (PDT) dari ketiga kelompok dianalisis menggunakan uji Kruskal Wallis.

Hasil: SPL menunjukkan kecepatan proliferasi yang berbeda saat dikultur dalam DMEM/5\% PRP, DMEM/10\% PRP dan MesenCult ${ }^{\circledR}$. PDT ketiga kelompok pada pasase 1-5 menunjukkan perbedaan bermakna $(p<0,05)$, dengan urutan PDT terendah pada kultur dengan medium DMEM/10\% PRP.

Kesimpulan: Hasil penelitian kami menunjukkan bahwa DMEM/10\% PRP dapat digunakan untuk menggantikan FBS pada medium kultur SPL. (Med J Indones. 2013;22:146-51. doi: 10.13181/mji.v22i3.583)

\begin{abstract}
Background: Lipoaspirate-derived stem cells (LSCs) are very promising for regenerative medicine, e.g. to treat acute myocard infarction. Fetal bovine serum (FBS) is commonly used to propagate the LSCs. However, for its clinical application, FBS contains xeno-proteins that are potential to elicit immune rejection in patients. Platelet rich plasma (PRP) is one of the candidates to replace FBS. This study aimed to compare the proliferation of LSCs cultured in 5\% PRP, 10\% PRP, and FBS containing medium (MesenCult巴).

Methods: LSCs were cultured in 5\% PRP/DMEM, 10\% PRP/DMEM, and MesenCult ${ }^{\circledR}$. After the primary culture reached its confluency, cells were harvested using TrypLE Select and seeded (around 20,000 viable cells) in new vessels in the same media. Passages were done until passage-5, with six replications. Population doubling time (PDT) of the three groups were analyzed using Kruskal Wallis test.

Results: LSCs showed different proliferation rates when cultured in 5\% PRP/DMEM, 10\% PRP/DMEM, and MesenCult ${ }^{\circledR}$. PDT of the three experimental groups in passage $1-5$ were significantly different $(p<0.05)$, with the lowest rank was cultured in medium of $10 \% \mathrm{PRP} / \mathrm{DMEM}$.

Conclusion: The results suggest that 10\% PRP/DMEM can be used as an alternative to replace FBS in LSC culture. (Med J Indones. 2013;22:146-51. doi: 10.13181/mji.v22i3.583)
\end{abstract}

Keywords: Fetal bovine serum, lipoaspirate, platelet rich plasma, stem cell

Adipose tissue is a rich source of mesenchymal stem cells (MSCs), which are very promising for regenerative medicine, due to their potential to differentiate into various types of cells. ${ }^{1,2}$ For clinical application, e.g. to cure acute myocard infarction, a large amount of stem cells, several hundred millions to ten billions are required. ${ }^{3}$ Therefore, stem cells need to be propagated by in vitro culture.

Stem cell culture needs growth factors that are usually provided by fetal bovine serum (FBS), which is added into the medium. MesenCult ${ }^{\circledR}$ is a commercially available medium, specially designed for isolation and expansion of MSCs, and consists of basal medium and FBS-derivate containing supplement. However, for clinical application, MSC culture should avoid animal derived materials such as FBS and fetal calf serum (FCS), because animal serum contains xeno-proteins such as Neu $5 \mathrm{GC}$, which may trigger immune response in recipients. ${ }^{4}$ Therefore, for clinical application in patients, xeno-free material should be used. Unfortunately, available xeno-free materials, e.g. xeno-free MesenCult $\AA$ is very expensive. 
To find cheaper alternative animal serum-free medium, platelet rich plasma (PRP) or thrombocyte concentrate in human plasma that contains various growth factors, or human $\mathrm{AB}$ serum can be considered as FBS substitute.

A critical review concluded that activated or lysed PRP or human AB serum can substitute FBS. They are better or comparable with FBS in supporting the proliferation of lipoaspirate-derived stem cells (LPS). ${ }^{5}$ Rauch, et $\mathrm{al}^{6}$ found that processed PRP contained platelet derived growth factor (PDGF-AB), epidermal growth factor (EGF), basic fibroblast growth factor (bFGF), hepatocyte growth factor (HGF), transforming growth factor- $\beta 1$ (TGF- $\beta 1)$ and vascular endothelial growth factor (VEGF) in higher levels compared to the levels in serum. ${ }^{6}$

Nevetheless, PRP utilization procedure has not been standardized yet. Various studies used various methods in getting, lysing or activating the PRP to release the growth factors. The growth factors can be released from the trombocyte's $\alpha$-granules using various methods, including freeze-thaw cycles at $-20^{\circ} \mathrm{C},-80^{\circ} \mathrm{C}$, or by thrombin or $\mathrm{CaCl}_{2}$ activation. ${ }^{5}$ Lysis of $\alpha$-granules should be easier in PRP after the expiry date, i.e. more than five days; thus it can not be used for direct clinical application anymore, but still can be used as supplement in culture medium as the growth factors can stand for around three weeks. ${ }^{6}$ Further more, those studies did not compare the results of primary cultures. Comparisons were only done after subcultures, while primary cultures were done in FBS containing medium. ${ }^{5}$

Considering the requirement to find cheaper xeno-free material to substitute FBS usage in culture medium and the facts that PRP can be one of the candidates for it, we conducted an in vitro culture study to know whether PRP was comparable to FBS to be used as culture supplement by studying the effect of PRP containing medium on human LSC proliferation compared to the commercial FBS containing medium, MesenCult $\AA$.

\section{METHODS}

This is an experimental analytic study that was conducted in the Integrated Laboratory of the Faculty of Medicine, Universitas Indonesia, from July 2012 through January 2013. Procedure of this study was approved by the Ethical Committee of the Faculty of Medicine Universitas Indonesia (no. 136/PT 02.FK/ ETIK/2012).

\section{Isolation and LCS culture}

Lipoaspirate samples were collected from seven healthy female donors, who underwent liposuction procedure in Medika Persada Clinic, Jakarta. Lipoaspirate samples were obtained after the donors signed the informed consent form. The lipoaspirate was kept at $4^{\circ} \mathrm{C}$, in transport-medium containing sterile bottle, for less than 24 hours.

After washing using phosphate buffered saline (PBS: Sigma P3813), lipoaspirate was digested by a two-fold volume of $0.075 \%$ collagenase type 1 (Gibco C17 100017) for one hour, as was previously described. ${ }^{7}$ The digest was centrifuged at $1,250 \mathrm{rpm}$. The resulting pellet was subjected to lysis buffer, and centrifuged for the second time. Finally, the pellet was resuspended in PBS. Cells were counted using Neubauer hemocytometer, and trypan blue was used to distinguish viable from dead cells.

For primary culture, $\pm 3-6 \times 10^{4}$ viable cells $/ \mathrm{cm}^{2}$ were seeded (in duplo) in a twelve-well plate, in complete MesenCult ${ }^{\circledR}$ (Stem Cell technologies basal medium 05401, Stem Cell technologies stimulatory 05402), Dulbecco modified Eagle's medium high glucose (Lonza C15-604 F, DMEM-HG) supplemented with human AB type PRP (Indonesian Red Cross) 5\%, and $10 \%$. All medium contained final concentrations of 100 units (U) penicillin/100 $\mu \mathrm{g}$ streptomycin/ $\mathrm{mL}$ (Gibco C15140), and amphotericin B 2,5 $\mu \mathrm{g} / \mathrm{mL}$ (JR Scientific C20025). For PRP containing medium, a final concentration of $2 \mathrm{U} / \mathrm{mL}$ heparin (Inviclot) was added to prevent clotting. Before use, the expired PRP was lysed by freezing at $-20^{\circ} \mathrm{C}$, then thawed.

The culture was observed daily, and when the cells attached to the vessel, they were washed by PBS, and the medium was changed. Further, medium change was done every two to three days. When the primary cultures (P0) were $70-90 \%$ confluent, they were detached by TrypLE Select, and viable cells were counted. For passages, if there were enough cells, around 20,000 viable cells (according to Mitchell, et al ${ }^{8}: 5000$ cells/ $\mathrm{cm}^{2}$ ) were seeded in a 12-well plate in duplicates, in the respective medium. However, for passage 1 and 2 of sample 1, seeding was done by splitting one into two wells. Passages were done until passage-5.

\section{Differentiation test}

Differentiation tests were done on passage- 2 cells that were cultured in $10 \%$ PRP containing medium using a differentiation kit for adipogenic, osteogenic, and chondrogenic differentiation (Stem Cell Kits SC 006), which were done according the procedures in the kit 
manual. The results of adipogenic, osteogenic, and chondrogenic differentiation were stained by oil red $\mathrm{O}$ (Amressco 0684-100G), alizarin red (Amressco 9436$25 \mathrm{G}$ ), and alcian blue (Amressco 0298-50G), respectively. Differentiation test results were noted and tabulated.

\section{Data collection and analysis}

Data collected from lipoaspirate donors were: age, body mass index (BMI), and time between liposuction procedure and the beginning of laboratory processing. The growing cells were observed morphologically, and the morphology in each medium was noted. The amount of cells that were seeded and harvested for each medium and passage were counted and noted. Further, the needed time from seeding to harvesting was noted, and population doubling time (PDT) for every passage and medium was computed, noted, and tabulated. Population doubling time was computed using the equation:

$$
\begin{aligned}
& \mathrm{PDT}=\frac{\log 2 \times \Delta \mathrm{T}}{\log (\mathrm{NH})-\log (\mathrm{NI})} \\
& \mathrm{NH}=\text { harvested cell number } \\
& \mathrm{NI}=\text { seeded cell number } \\
& \Delta \mathrm{t}=\text { time from seeding to harvesting }
\end{aligned}
$$

When the data was normally distributed, means and standard deviations (SDs) for each passage and medium were computed and tabulated. Otherwise, median, minimum and maximum values were used. Comparisons of PDT between MesenCult $\AA$, PRP 5\% and PRP 10\% containing medium for every passage were analyzed by one way ANOVA, when the data were normally distributed and homogenous, or by Kruskal Wallis test, when the data were the opposite. If there were significant differences, posthoc analyses using Mann-Whitney test were done. ${ }^{9}$ The data were processed using SPSS version 11.5.

\section{RESULTS}

From the seven lipoaspirates that were used in this study, the first sample can not be analyzed due to medium clotting in P0 of PRP containing medium, and fungal contamination in $\mathrm{P} 0$ of MesenCult $\AA$. Therefore, only six samples were analyzed.

Mean \pm standard deviation and range of donor age and BMI were $45.2 \pm 10.5$ (33-62) years, and $26.9 \pm 3.99$ (22.4-32.8), respectively. Among the analyzed samples there were 1 sample with obesity, 3 samples with excess body weight, and 2 samples with normal weight.

Mean \pm standard deviation and range of the time berween liposuction procedure and lipoaspirate processing were $10.6 \pm 4.28$ (3-17.5) hours. Processing yielded mean of viable cell number/gram of lipoaspirate, percentage of viable cell number, mean of non-viable cell number/gr of lipoaspirate, and percentage of non-viable cell number, which were 50,977.1 cells/gram (34.77\%), and 95,617.5 cells/gram $(65.23 \%)$, respectively.

Observation of primary culture cell growth (P0) in MesenCult巴 showed that the cells attached and became confluent faster compared to those in $10 \%$ PRP/DMEM-HG or 5\% PRP/DMEM-HG. However, cell growth of P1-P5 in MesenCult ${ }^{\circledR}$ was slower compared to those in 10\% PRP/DMEM-HG or 5\% PRP/DMEM-HG. Cell growth of P1-P5 in 10\% PRP/DMEM-HG was the fastest among three kinds of media. However, the growth rates were variative and inconsistent, as the time to become confluent was variative between passages and samples.

\section{Cell morphology}

On day-3, passage-1 cells in MesenCult ${ }^{\circledR}$ (seeding 133,500 viable cells/well) and 10\% PRP containing medium (seeding 79,500 viable cells/well) showed fibroblastic morphology, while cells in 5\% PRP containing medium (seeding 52,500 viable cells/well) showed fibroblastic morphology with short cytoplasmic processes, which were almost diamond shaped rather than fibroblastic, and the cytoplasm contained fine granules (Figure 1).
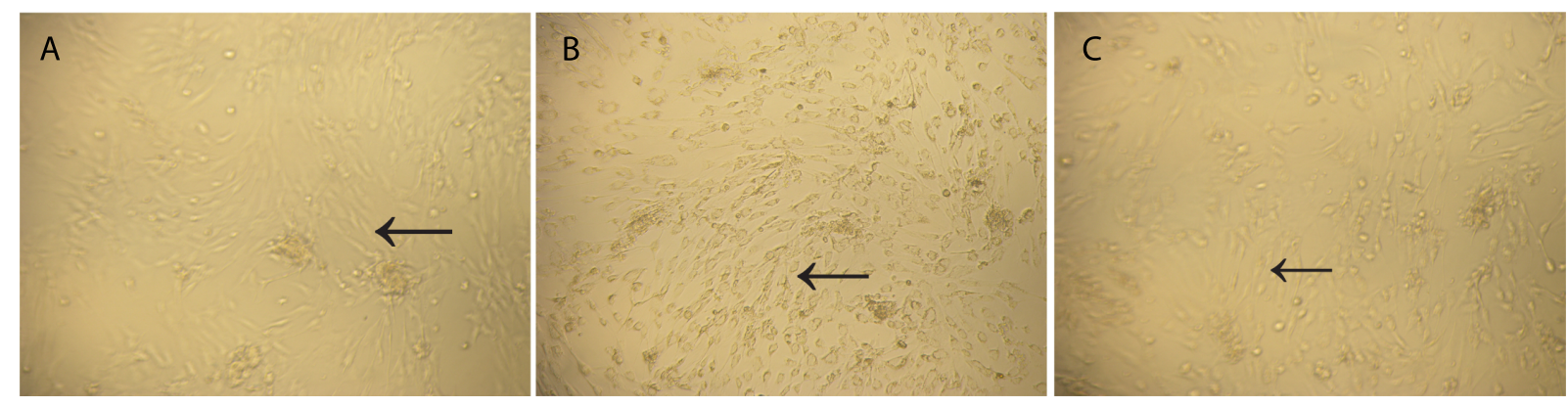

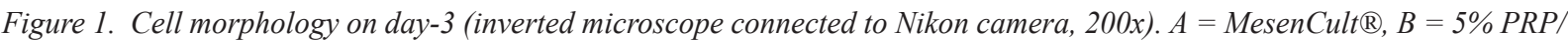
DMEM-HG, $C=10 \%$ PRP/DMEM-HG 
Observation of cell morphology in MesenCult ${ }^{\circledR}$ at harvest showed that the number of large cells increased with the increase of passage number (Figure 2).

\section{Result of differentiation test}

Differentiation test results of passage 1 of cells that were cultured in PRP 10\% containing medium showed that the cells could differentiate into adipocytes, which was proven by oil red $\mathrm{O}$ staining to show the lipid dropplets in the cytoplasm. Further, the cells could differentiate into osteogenic and chondrogenic cells, which were proven by alizarin red that stained calcification, and alcian blue that stained cartilage matrix, respectively.

\section{Population doubling time}

Primary cultures were harvested on day- 5 or -7 , but their PDT could not be analyzed due to the variable nature of seeded cells in primary cultures, which were a mixture of cells, and only part of those cells were stem cells that adhered to plastic, and had proliferation capacity. Therefore, the data analysis to compute PDT were only done on P1-P5 (Table 1).

\section{Data analysis}

Kruskal Wallis test to compare the PDT in the three kinds of media showed significant difference at passage $1-5$ between the three media $(\mathrm{p}<0.05)$, with the lowest rank at $10 \%$ PRP containing medium.

\section{DISCUSSION}

This study showed that cell growth observed from primary cultures (P0) in MesenCult $\AA$, the cells attached and became confluent faster compared to those cultured in $10 \%$ or $5 \% \mathrm{PRP} / \mathrm{DMEM}-\mathrm{HG}$. This fact might be due to various growth and attachment factors in the complete MesenCult ${ }^{\circledR}$ medium, which were not listed in the content list, as it is a patented medium.

For passage 1-5, lowest PDT was achieved by $10 \%$ PRP/DMEM-HG. Kakudo, et $\mathrm{al}^{10}$ found that $5 \%$ PRP

\begin{tabular}{|c|c|c|}
\hline MesenCult $(\mathbb{R}$ & PRP 5\% & PRP 10\% \\
\hline 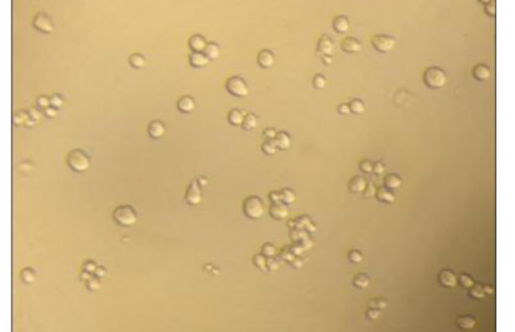 & e & 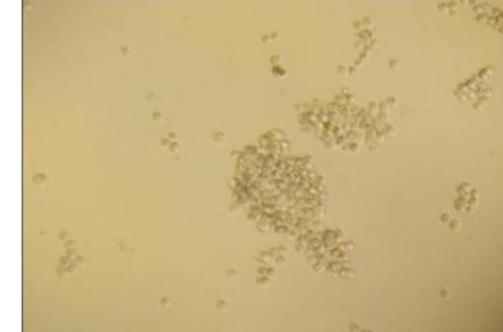 \\
\hline $\begin{array}{l}\text { Passage } 2-100 x \text { magnification, cell size } \\
\text { was variable with large cell dominancy }\end{array}$ & $\begin{array}{l}\text { Passage } 2-100 x \text { magnification, most- } \\
\text { ly small cells }\end{array}$ & $\begin{array}{l}\text { Passage } 2 \text { - 100x magnification, mostly } \\
\text { small cells }\end{array}$ \\
\hline
\end{tabular}

Figure 2. Cell size of sample number 7 that was cultured in three kinds of media after detachment from culture vessel at harvest

Table 1. Median, minimum, and maximum values of PDT and passage time

\begin{tabular}{lccccccccc}
\hline \multirow{2}{*}{$\mathrm{P}$} & \multicolumn{2}{c}{ MesenCult $\mathrm{R}$} & \multicolumn{2}{c}{$5 \%$ PRP/DMEM-HG } & \multicolumn{3}{c}{$10 \%$ PRP/DMEM-HG } \\
\cline { 2 - 9 } & PDT(d) & PT(d) & $\mathrm{n}$ & PDT(h) & PT(d) & $\mathrm{n}$ & PDT(d) & PT(d) & $\mathrm{n}$ \\
\hline P1 & $3.3(1.0-10.2)$ & $7(3-9)$ & 11 & $2.1(1.1-7.0)$ & $7(4-9)$ & 9 & $1.7(0.8-4.9)$ & $7(3-9)$ & 10 \\
P2 & $3.9(2.5-5.7)$ & $9(7-12)$ & 8 & $3.1(1.0-7.1)$ & $8(1-14)$ & 12 & $2.4(1.0-4.6)$ & $8(4-14)$ & 12 \\
P3 & $7.4(2.3-12.1)$ & $7(5-19)$ & 9 & $2.6(1.8-4.1)$ & $7(5-11)$ & 9 & $2.0(1.1-2.6)$ & $7(2-11)$ & 10 \\
P4 & $6.4(3.4-19.7)$ & $7(4-14)$ & 7 & $3.0(1.1-6.0)$ & $7(4-10)$ & 9 & $2.2(1.1-4.4)$ & $6(4-10)$ & 10 \\
P5 & $5.3(1.2-28.0)$ & $7(3-19)$ & 6 & $2.5(1.0-10.7)$ & $7(3-7)$ & 9 & $2.1(1.0-3.9)$ & $7(4-14)$ & 10 \\
\hline
\end{tabular}

$\mathrm{P}=$ passage, $\mathrm{PDT}=$ population doubling time, $\mathrm{d}=$ days, $\mathrm{PT}=$ passage time, $\mathrm{n}=$ sample number, the values are median (minimummaximum) 
was enough to support stem cell proliferation, non toxic, and did not elicit immune reaction, while higher concentration of PRP was toxic to cells that caused a decrease in cell growth. However, other studies corroborate our result, and found that 10\% PRP was superior in supporting stem cell proliferation compared to 5\% PRP containing medium. ${ }^{11,12}$ These variable results might be due to the difference in platelet count in the PRP, and the difference in processing the PRP to release the growth factors.

In addition, though cell growth of passage 1-5 in $10 \%$ PRP containing medium was faster, the time needed to become confluent was variable. This fact might be due to the freeze-thaw cycle, which was variable between 1-3 times due to the practice in aliquoting the PRP as $5 \mathrm{~mL}$ aliquots, and this fact was the limitation of our study. Therefore, before using PRP as supplement in culture medium for patient use, the PRP needs to be standardized in term of the platelet count and the processing to release the growth factors.

Computing PDT is one of the methods to monitor and quantitatively analyze the result of cell cultures, ${ }^{13}$ which can assess culture medium quality. At passages, PDT of the cells in MesenCult ${ }^{\circledR}$ took longer time compared to those in $10 \%$ or $5 \%$ PRP containing medium, and the PDT in MesenCult $\AA$ was increased with increasing passage. This phenomenon might be due to the various growth factors and substances in MesenCult ${ }^{\circledR}$ that promoted spontaneous cell differentiation, which could be seen from the appearance of large cells (Figure 2).

The time needed by stem cells to undergo one mitosis cycle in vitro is $1-3$ days. ${ }^{13}$ According to Dominici, et al the criteria of MSCs in culture are attachment to plastic, and fibroblastic in morphology. ${ }^{14}$ In addition, they should bear certain surface markers that are characteristics of MSCs, and the cells should be able to differentiate into three mesenchymal lineages upon appropriate induction. Therefore, in our study, the cells that grew in $10 \%$ PRP containing medium were MSCs, as they were adherent to plastic, fibroblastic in morphology, the PDT were between 1-3 days, and passage-1 cells could differentiate into three mesenchymal lineages.

The cells that grew in 5\% PRP/DMEM-HG showed fibroblastic morphology, had short cytoplasmic processes, and contained fine granules (vesicles) in passage-1 culture (Figure 1). A study showed that adipose tissue derived MSCs, which were cultured in human AB serum and thrombin activated PRP (tPRP) containing medium appeared similar, i.e. they were fibroblastic, had fewer cytoplasmic processes, and contained vesicles around the nucleus. Those cells were shown to be MSCs based on their surface markers and differentiation capacity. ${ }^{12}$ Human AB serum and tPRP containing medium might contain similar amount of growth factors as 5\% PRP containing medium, which is less than $10 \%$ PRP containing medium. We supposed that minimal amount of growth factors still support MSC proliferation.

Current good manufacturing practices (cGMPs) emphasize the safety, efficacy, and quality of adult stem cells to be used in clinical application. Therefore, for clinical application, a sufficient amount of cells should be isolated from tissues, and when it is needed, the cells can be propagated by culturing in appropriate medium, while the differentiation capacity should be preserved. In addition, culture condition should be able to propagate the cells in minimal passage, as long-term in vitro culture might change the biological properties. ${ }^{15,16}$ Moreover, for safety measures, xeno-derived materials should be avoided due to the possibility of antigen-antibody reaction against the xenogenic material. ${ }^{4}$ Substituting FBS, which is usually added to culture medium, with human serum or lysed or activated PRP was reported to give better results in supporting proliferation and differentiation capacity of adipose tissue derived MSCs, ${ }^{10-12}$ and this study showed similar results.

Our study showed that medium, which contained $10 \%$ PRP from Indonesian Red Cross that was lysed by a freeze-thaw cycle at $-20^{\circ} \mathrm{C}$, was better than the commercial medium MesenCult ${ }^{\circledR}$ at passage 1-5 of adipose tissue derived mesenchymal stem cells, though for primary culture, MesenCult ${ }^{\circledR}$ was better. For primary culture of adipose tissue derived mesenchymal stem cell, 10\% PRP containing medium can be used, but a longer time is needed to achieve confluence.

In conclusion, medium containing 10\% PRP (from Indonesian Red Cross) is a good and economical alternative to FBS containing medium for lipoaspirate derived mesenchymal stem cell.

\section{Acknowledgment}

The authors greatly appreciate the cooperation of the lipoaspirate donors, and are greatly indebted for their lipoaspirate donation.

\section{Funding}

This study was funded by the grant from Directorate of Research and Community Service of Universitas Indonesia 2012, contract no.1594/H2.R12/HKP.05.00/2012. 


\section{REFERENCES}

1. Pawitan JA. Prospect of adipose tissue derived mesenchymal stem cells in regenerative medicine. Cell \& Tissue Transplantation \& Therapy. 2009;2:7-9.

2. Lindroos B, Suuronen R and Miettinen S. The potential of adipose stem cells in regenerative medicine. Stem Cell Rev. 2011;7(2):269-91.

3. Shah VK, Shalia KK. Stem Cell Therapy in Acute Myocardial Infarction: A Pot of Gold or Pandora's Box. Stem Cells International. 2011;2011:1-20.

4. Spees JL, Gregory CA, Singh H, et al. Internalized antigens must be removed to prepare hypoimmunogenic mesenchymal stem cells for cell and gene therapy. Mol Ther. 2004;9(5):747-56.

5. Pawitan JA. Platelet rich plasma in xeno-free stem cell culture: the impact of platelet count and processing method. Curr Stem Cell Res Ther. 2012;7(5):329-35.

6. Rauch C, Feifel E, Amann EM, et al. Alternatives to the use of fetal bovine serum: human platelet lysates as a serum substitute in cell culture media. ALTEX. 2011;28(4):305-16.

7. Pawitan JA, Liem IK, Suryani D, Bustami A, Purwoko RY. Simple lipoaspirate washing using a coffee filter. Asian Biomedicine. 2013;7(3):333-8.

8. Mitchell JB, McIntosh K, Zvonic S, et al. Immunophenotype of human adipose-derived cells: temporal changes in stromal-associated and stem cell-associated markers. Stem Cells. 2006;24(2):376-85.

9. Pallant J. SPSS Survival Manual: a step by step guide to data analysis using SPSS. $2^{\text {nd }}$ ed. Australia: Allen \& Unwin;2005.
10. Kakudo N, Minakata T, Mitsui T, Kushida S, Notodihardjo FZ, Kusumoto K. Proliferation-promoting effect of platelet-rich plasma on human adipose-derived stem cells and human dermal fibroblasts. Plast Reconstr Surg. 2008;122(5):1352-60.

11. Kocaoemer A, Kern S, Kluter H, Bieback K. Human AB serum and thrombin-activated platelet-rich plasma are suitable alternatives to fetal calf serum for the expansion of mesenchymal stem cells from adipose tissue. Stem Cells. 2007;25(5):1270-8.

12. Bieback K, Hecker A, Kocaömer A, et al. Human alternatives to fetal bovine serum for the expansion of mesenchymal stromal cells from bone marrow. Stem Cells. 2009;27(9):2331-41.

13. Korzyńska A, Zychowicz A. A method of estimation of the cell doubling time on basis of the cell culture monitoring data. Biocybernetics and Biomedical Engineering. 2008; 28(4):75-82.

14. Dominici M, Le Blanc K, Mueller I, et al. Minimal criteria for defining multipotent mesenchymal stromal cells. The International Society for Cellular Therapy position statement. Cytotherapy. 2006;8(4):315-7.

15. Boquest AC, Shahdadfar A, Frønsdal K, et al. Isolation and transcription profiling of purified uncultured human stromal stem cells: alteration of gene expression after in vitro cell culture. Mol Biol Cell. 2005;16(3):1131-41.

16. Izadpanah $\mathrm{R}$, Kaushal $\mathrm{D}$, Kriedt $\mathrm{C}$, et al. Long-term in vitro expansion alters the biology of adult mesenchymal stem cells. Cancer Res. 2008;68(11):4229-38 